\title{
PENGARUH KOMPOSISI MEDIA TANAM DAN KONSENTRASI PUPUK HAYATI AGROBOST TERHADAP PERTUMBUHAN DAN PRODUKSITANAMAN SAWI HIJAU (Brassica juncea L.) DALAM POLYBAG
}

\author{
Missdiani*11), Lusmaniar1), Pipit Hariani²) \\ 1)Dosen Fakultas Pertanian Universitas Tamansiswa Palembang \\ 2)Alumni Fakultas Pertanian Universitas Tamansiswa Palembang \\ "Email : missdianimuzar@gmail.com
}

\begin{abstract}
This study aims to measure the effect of planting media and the concentration of biofertilizer agrobost on the growth and production of mustard greens (Brassica juncea L.). The study used a factorial randomized block design consisting of two treatment factors with 16 treatment combinations and 3 replications, so that there were 48 treatment plot combinations.

The results showed that the treatment of M4 growing media (soil + manure + cocopeat) affected the number of leaves, wet stubble weight, production per plant and production per hectare. The concentration of biofertilizer agrobost $\mathrm{H} 1$ ( $5 \mathrm{ml} / /$ water) has an effect on crop wet weight, crop production and production per hectare. The interaction of soil planting medium + occasional fertilizer + cocopeat and $5 \mathrm{ml} /$ / water (M4H1) agrobost bio-fertilizer concentration had the best effect on seeds per plot and seed production per hectare.
\end{abstract}

Key words: Mustard, planting media, biological fertilizer

\begin{abstract}
ABSTRAK
Penelitian ini bertujuan untuk mengetahui pengaruh komposisi media tanam dan konsentrasi pupuk hayati agrobost terhadap pertumbuhan dan produksi tanaman sawi hijau (Brassica juncea L.). Penelitian ini menggunakan Rancangan Acak Kelompok faktorial yang terdiri dari dua faktor perlakuan dengan 16 kombinasi perlakuan dan 3 kali ulangan, sehingga terdapat 48 kombinasi petak perlakuan.

Hasil penelitian menunjukkan bahwa perlakuan media tanam $\mathrm{M}_{4}$ (tanah+pupuk kandang+cocopeat) berpengaruh terbaik terhadap jumlah daun, berat berangkasan basah, produksi per tanaman dan produksi per hektar. Konsentrasi pupuk hayati agrobost $\mathrm{H}_{1}(5 \mathrm{ml} / \mathrm{l}$ air) berpengaruh terbaik terhadap berat berangkasan basah tanaman, produksi tanaman dan produksi per hektar. Interaksi perlakuan media tanam tanah+pupuk kadang+cocopeat dan konsentars pupuk hayati agrobost $5 \mathrm{ml} / \mathrm{l}$ air $\left(\mathrm{M}_{4} \mathrm{H}_{1}\right)$ berpengaruh terbaik terhadap berat biji per petak dan produksi biji per hektar.
\end{abstract}

Kata Kunci : Sawi, media tanam, pupuk hayati

\section{PENDAHULUAN}

Tanaman sawi hijau (Brassica juncea L.) merupakan salah satu komoditas hortikultura sayuran daun yang banyak digemari oleh masyarakat karena rasanya enak, mudah didapat, dan budidayanya tidak terlalu sulit. Tanaman sawi hijau banyak mengandung $2,3 \mathrm{~g}$ protein; $0,3 \mathrm{~g}$ lemak; 4,0 g karbohidrat; $220 \mathrm{mg} \mathrm{Ca;} 38 \mathrm{mg} \mathrm{P} ; 6,4 \mathrm{~g}$ vitamin $A ; 0,09 \mathrm{mg}$ vitamin $\mathrm{B} ; 102 \mathrm{mg}$ vitamin $\mathrm{C}$; serta $92 \mathrm{~g}$ air (Direktorat Tanaman Sayuran dan Tanaman Hias, 2012), juga merupakan salah satu komoditas sayuran yang mempunyai

nilai

komersial dan prospek yang tinggi ( Fuad, 2010).

Permintaan akan komoditas sayuran mengalami peningkatan, hal ini berdasarkan data Dirjen Hortikultura (2010). Bermacam-macam jenis sayuran yang dapat dibudidayakan adalah tanaman sawi hijau (Brassica juncea L.), yang merupakan salah satu komoditas yang mempunyai nilai komersial dan prospek yang tinggi (Fuad, 2010)

Mengingat nilai ekonomi dan manfaatnya bagi kesehatan, maka perlu dilakukan upaya untuk meningkatkan produksi sawi. Hayati et al. (2012) 
mengatakan bahwa faktor lingkungan sangat berperan dalam proses pertumbuhan tanaman, media tumbuh adalah salah satu faktor lingkungan yang perlu dipertimbangkan, media tanam yang baik biasanya digunakan campuran pasir, tanah, dan pupuk kandang. Penggunaan pasir sangat baik untuk perbaikan sifat fisik tanah terutama tanah liat.

Menurut Wuryaningsih (2008) media tanam adalah media yang digunakan untuk menumbuhkan tanaman, tempat akar atau bakal akar akan tumbuh dan berkembang, juga digunakan tanaman sebagai tempat berpegangnya akar, agar tajuk tanaman dapat tegak kokoh berdiri di atas media tersebut dan sebagai sarana untuk menghidupi tanaman. Wira (2000) menambahkan bahan-bahan untuk media tanam dapat dibuat dari bahan tunggal ataupun kombinasi dari beberapa bahan, asalkan tetap berfungsi sebagai media tumbuh yang baik. Berbagai bahan yang dapat digunakan sebagai media tanam yaitu dapat berupa bahan tanah atau bahan bukan tanah. Bahan bukan tanah dapat merupakan bahan organik dan bahan anorganik. Bahan organik yang umum dipakai untuk media tumbuh antara lain: sekam padi, serbuk sabut kelapa (Cocopeat), serbuk gergaji dan arang, sedangkan bahan anorganik antara lain pasir dan batu bata (Daniel, 2008).

Hasil penelitian Risyad dan Ainun (2014), menunjukkan bahwa perlakuan media tanam berpengaruh sangat nyata meningkatkan panjang tanaman umur 10 hari dan 20 hari setelah tanam (hst), diameter batang umur 10, 20 dan 30 hari setelah tanam (hst) dan berpengaruh nyata meningkatkan panjang tanaman umur 30 hst, panjang tanaman 25 ruas (saat toping), bobot buah, panjang buah dan diameter buah pada media tanam top soil + pupuk kandang + cocopeat pada tanaman melon.

Kebutuhan unsur hara tanaman dapat ditambahkan melalui pemupukan. Salah satu jenis pupuk yang mulai mendapat perhatian petani selain pupuk kimia dan pupuk organik adalah pupuk hayati. Pupuk hayati (biofertilizer), adalah jenis pupuk yang mengandung mikrooganisme yang memiliki peranan positif bagi tanaman yaitu membantu menyediakan hara yang dibutuhkan tanaman. Kelompok mikroba yang sering digunakan dalam pupuk hayati adalah mikroba-mikroba yang dapat menambat $\mathrm{N}$ dari udara, mikroba yang melarutkan hara $\mathrm{P}$ dan $\mathrm{K}$. Kelompok mikroorganisme tersebut adalah Rhizobium, Azospirilium, Azotobacter sp, Aspergilus, Psudomonas sp, dan Lactobacillus (Isroi, 2008).
Salah satu pupuk hayati yang dikenal adalah pupuk Agrobost. Keuntungan Agrobost dapat mengurangi pupuk kimia sampai $50 \%$ atau sekaligus dapat meningkatkan produktivitas, dalam pupuk Agrobost terdapat beberapa mikroba penting yang dibutuhkan dalam proses penyuburan tanah seperti Azospirillum, Azotobacter, Mikroba Pelarut $P$, Lactobacillus, mikroba pendegradasi selulosa, hormon tumbuh Indole Acetic Acid, dan enzim selulase. Jenis-jenis mikroba dan enzim tersebut dapat bekerja secara maksimal sehingga terjadi penghematan penggunaan pupuk kimia (Agro Dahlia Profitmas, 2008).

Kandungan yang terdapat di dalam Agrobost yaitu Azotobacter sp. $7.5 \times 107 \mathrm{sel} / \mathrm{ml}$, Azospirillium sp. $2.0 \times 105 \mathrm{sel} / \mathrm{ml}$, Mikroba pelarut phosphate 1.7 x $107 \mathrm{sel} / \mathrm{ml}$, Lactobacillus sp $4.7 \times 105 \mathrm{sel} / \mathrm{ml}$, Mikroba Selulolitik 6.0 × $102 \mathrm{sel} / \mathrm{ml}$, Pseudomonas sp $1,7 \times 106 \mathrm{sel} / \mathrm{ml}$, Unsur mikro : $\mathrm{C}$ organic $=$ $0.95 \%, \mathrm{P}=34.29 \mathrm{ppm}, \mathrm{K}=1743 \mathrm{ppm}, \mathrm{Fe}=44.3$ $\mathrm{ppm}, \mathrm{Mn}=0.27 \mathrm{ppm}, \mathrm{Cu}=0.81 \mathrm{ppm}, \mathrm{Zn}=3.7 \mathrm{ppm}$ (Agro Dahlia profitamas, 2008).

Hasil penelitian Astari, (2014) dalam Risyad dan Ainun (2014), pengaplikasian Agrobost memberikan pengaruh terhadap diameter batang, panjang akar serta berat basah dan kering akar tanaman tomat. Selanjutnya Risyad dan Ainun (2014) menyatakan bahwa pemberian Agrobost konsentrasi $7.5 \mathrm{ml} / \mathrm{l}$ air pada melon, berpengaruh nyata meningkatkan panjang tanaman umur $30 \mathrm{hst}$, diameter batang umur $30 \mathrm{hst}$ dan bobot buah.

Berdasarkan dengan uraian diatas maka perlu dilakukan penelitian untuk mengetahui pengaruh komposisi media tanam dan konsentrasi pupuk hayati agrobost terhadap pertumbuhan dan produksi tanaman sawi hijau (Brassica juncea L.) dalam polybag.

Penelitian ini bertujuan untuk mengetahui pengaruh komposisi media tanam dan konsentrasi pupuk hayati Agrobost terhadap pertumbuhan dan produksi tanaman sawi hijau (Brassica juncea L.) dalam polybag.

\section{METODE PENELITIAN}

Penelitian dilaksanakan di Desa Karang Anyar Kabupaten Semendawai Timur Kabupaten OKU Timur.

Bahan yang digunakan dalam penelitian ini adalah benih sawi hijau, pupuk hayati Agrobost, polybag berukuran $35 \times 40 \mathrm{~cm}(5 \mathrm{~kg})$, tanah, pupuk kandang sapi, arang sekam, cocopeat (serbuk sabut kelapa), NPK Phonska dan Insektisida Furadan 3G. Alat yang digunakan adalah ember, timbangan, cangkul, parang, gunting, pisau cutter, saringan, 
penggaris, kalkulator, alat tulis, dan alat dokumentasi.

Penelitian ini menggunakan Rancangan Acak Kelompok (RAK) faktorial yang terdiri dari dua faktor perlakuan yaitu media tanam dan (M) dan konsentrasi pupuk hayati agrobost $(\mathrm{H})$ dan tiga ulangan.

1. Perlakuan media tanam yang terdiri dari :

$$
\begin{aligned}
M_{1}= & \text { (tanah) } \\
M_{2}= & \text { (tanah }+ \text { pupuk kandang) dengan } \\
& \text { perbandingan volume }(2: 1) \\
M_{3}= & \text { (tanah }+ \text { pupuk kandang }+ \text { arang sekam }) \\
& \text { dengan perbandingan volume }(1: 1: 1) \\
M_{4}= & \text { (tanah }+ \text { pupuk kandang }+ \text { cocopeat }) \\
& \text { dengan perbandingan volume }(1: 1: 1) .
\end{aligned}
$$

2. Konsentrasi pupuk hayati Agrobost yang terdiri dari :

$$
\begin{aligned}
& \mathrm{H}_{0}=\text { tanpa pupuk (control) } \\
& \mathrm{H}_{1}=5 \mathrm{ml} / \mathrm{l} \text { air } \\
& \mathrm{H}_{2}=7,5 \mathrm{ml} / \mathrm{l} \text { air } \\
& \mathrm{H}_{3}=10 \mathrm{ml} / \mathrm{lair}
\end{aligned}
$$

Apabila data hasil analisis keragaman menunjukkan hasil berpengaruh nyata, maka untuk mengetahui perbedaan antara perlakuan digunakan Uji Beda Nyata Jujur (BNJ).

\section{Prosedur Kerja}

\section{Persemaian}

Media semai yang disiapkan berupa tanah halus, pupuk kandang/kompos dengan perbandingan 1:1,

benih direndam kemudian disemai di media tanam yang telah disiapkan. Bibit sawi dapat ditanam setelah berumur dua sampai tiga minggu atau telah berdaun empat sampai lima helai.

\section{Persiapan Media Tanam}

Bahan media tanam yang telah dipersiapkan dicampur sesuai dengan perlakuan. Perbandingan media tanam ditentukan berdasarkan volume dengan rincian sebagai berikut:

$\mathrm{M}_{1}=$ Media tanam terdiri dari tanah.

$\mathrm{M}_{2}=2$ (dua) bagian tanah dicampur dengan 1 (satu) bagian pupuk kandang sapi.

$M_{2}=1$ (satu) bagian tanah dicampur dengan 1 (satu) bagian pupuk kandang sapi dan 1 (satu) bagian arang sekam

$\mathrm{M}_{3}=1$ (satu) bagian tanah dicampur dengan 1 (satu) bagian pupuk kandang sapi dan 1 (satu) bagian cocopeat
Pencampuran media tanam dan pengisian ke dalam polybag dilakukan dua minggu sebelum tanam, campuran media tanam untuk setiap perlakuan diisi ke dalam polybag berukuran 35 x 40 $\mathrm{cm}$, lalu disusun sesuai perlakuan dan dibiarkan dalam keadaan terbuka.

\section{Pemberian Pupuk Dasar dan Insektisida}

Pupuk dasar yang digunakan adalah NPK (15:15:15) dengan dosis $7 \mathrm{~g}$ per polybag. Pemberian dilakukan sehari sebelum tanam dan bersamaan dengan pemberian pupuk dasar juga diberikan Insektisida Furadan 3G sebanyak lima g per polybag bertujuan untuk mengendalikan hama dalam media tanam.

\section{Penanaman}

Penanaman dilakukan dengan cara meletakkan bibit (berumur 14 hari atau telah berdaun empat sampai

lima helai) langsung pada lubang polybag dengan kedalaman kira-kira $5 \mathrm{~cm}$.

\section{Aplikasi perlakuan}

Konsentrasi Pupuk Hayati Agroobost sesuai perlakuan masing-masing diberikan sebanyak tiga kali yaitu, satu minggu setelah tanam (mst), dua mst, dan tiga mst. Pemberian pupuk dilakukan dengan menyiram secara langsung ke permukaan tanah dalam polybag secara merata, dengan volume penyemprotan $150 \mathrm{ml}$ larutan Agrobost per aplikasi per polybag.

\section{Pemeliharaan Tanaman}

a. Penyiraman Penyiraman dilakukan dua kali sehari yaitu pada pagi dan sore hari.

b. Penyiangan

Penyiangan dilakukan umur 10 hari setelah tanam dan dilakukan secara manual dengan mencabut rumput/gulma yang tumbuh.

c. Pengendalian Hama Penyakit Pengendalian hama dan penyakit dilakukan apabila tanaman terserang hama dan penyakit.

\section{Panen}

Pemanenan dilakukan pada umur 30-45 hari setelah tanam. Kriteria panen adalah tinggi tanaman kurang lebih $30 \mathrm{~cm}$, lalu dipanen dengan cara tanah 
dibasahi dulu sehingga tanaman mudah dicabut secara hati-hati.

\section{Peubah yang Diamati}

Peubah yang diamati dalam penelitian adalah Tinggi Tanaman (cm), Jumlah Daun (helai), Berat Basah Tanaman (g), Produksi Per Tanaman (kg), Produksi Per Hektar (ton)

\section{HASIL DAN PEMBAHASAN}

Hasil

Berdasarkan hasil analisis keragaman pengaruh komposisi media tanam dan konsentrasi pupuk hayati Agrobost bahwa perlakuan media tanam (M) terhadap tinggi tanaman dan jumlah daun menunjukkan pengaruh yang tidak nyata dan berpengaruh nyata pada berat berangkasan basah, produksi per tanaman dan produksi per hektar. Semua perlakuan konsentrasi pupuk hayati Agrobost $(\mathrm{H})$ dan interaksi media tanam dan konsentrasi pupuk hayati Agrobost (MxH) menunjukkan pengaruh yang tidak nyata terhadap peubah yang diamati. Hasil analisis keragaman terhadap semua peubah yang diamati disajikan pada Tabel 3.

Tabel 3. Hasil analisis keragaman terhadap semua peubah yang diamati

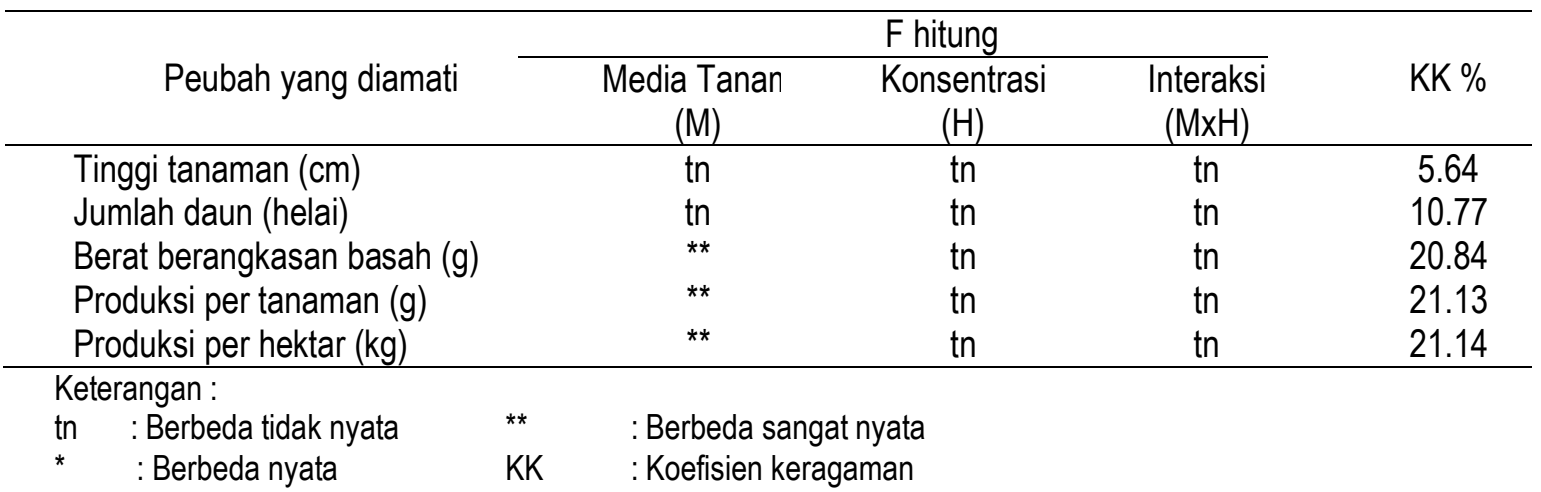

1. Tinggi Tanaman (cm).

Pengaruh perlakuan media tanam terhadap tinggi tanaman sawi hijau dapat dilihat pada Gambar 1.

Berdasarkan gambar 1 bahwa perlakuan media tanam menghasilkan pertumbuhan tinggi tanaman sawi hijau tertinggi terdapat pada media tanam $\mathrm{M}_{4}$ (tanah + pupuk kandang + cocopeat) yaitu $35,95 \mathrm{~cm}$ dan terendah pada media tanam $M_{1}$ (tanah) yaitu $33,13 \mathrm{~cm}$.

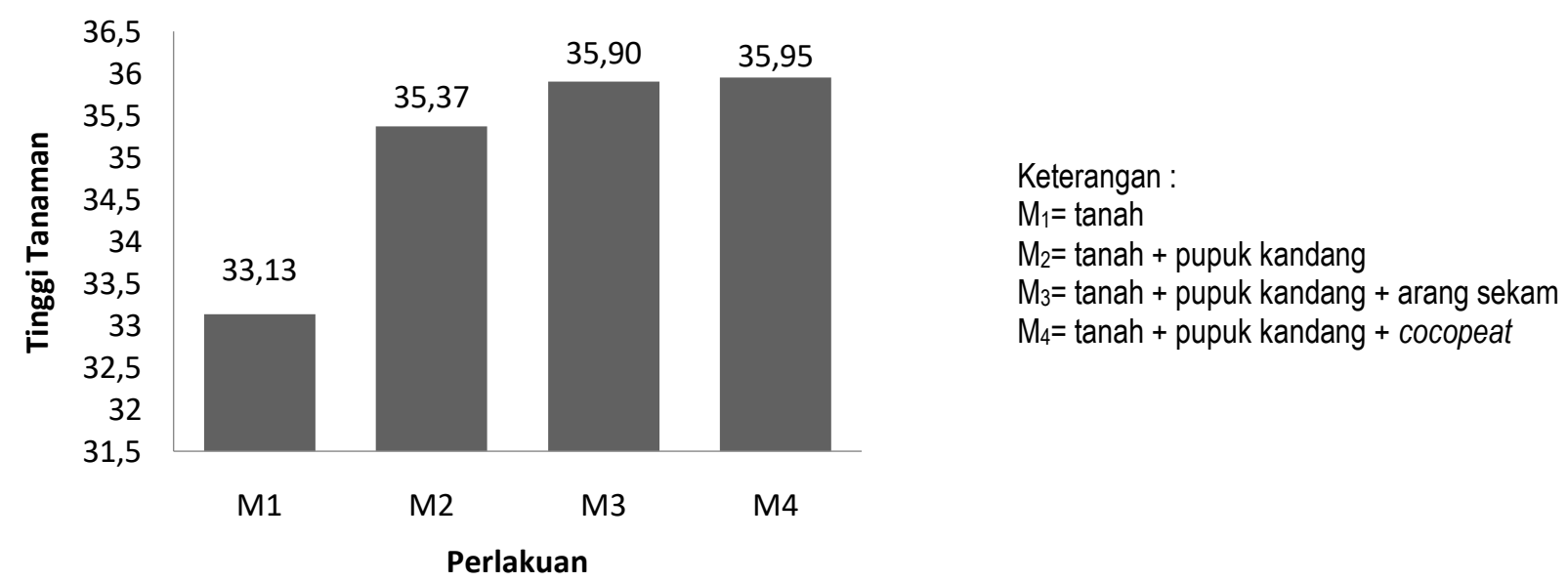

Gambar 1. Perlakuan media tanam terhadap rata-rata tinggi tanaman sawi hijau (Brassica juncea L). 


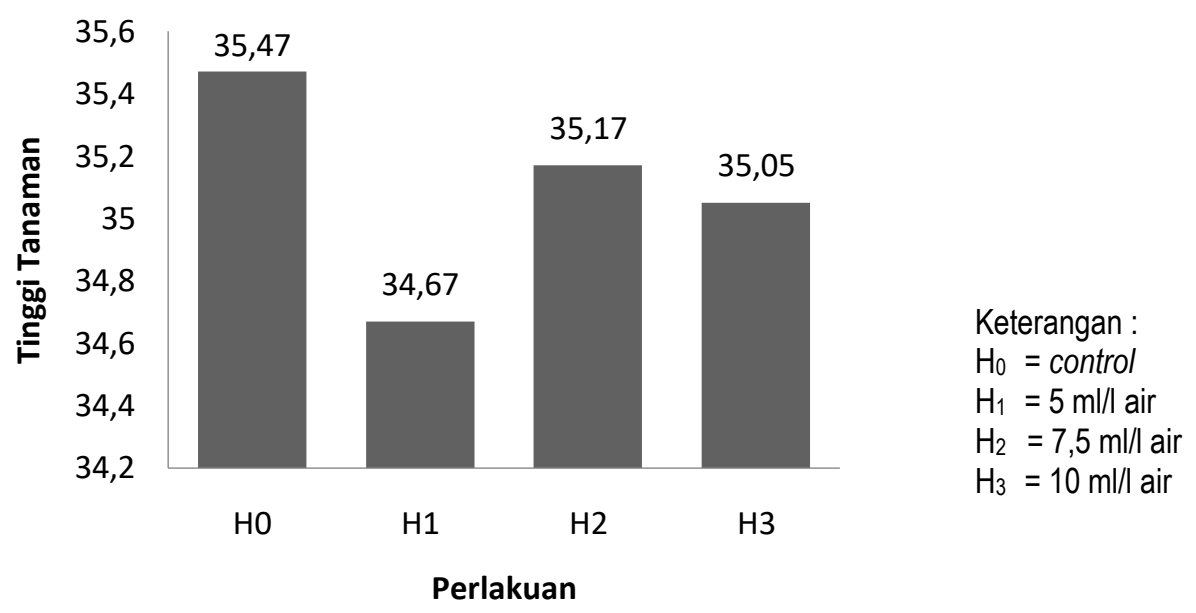

Gambar 2. Pengaruh konsentrasi pupuk hayati Agrobost terhadap rata-rata tinggi tanaman sawi hijau (Brassica juncea L).

Berdasarkan gambar di atas bahwa perlakuan konsentrasi pupuk hayati Agrobost menghasilkan pertumbuhan tinggi tanaman sawi hijau tertinggi yaitu pada konsentrasi $\mathrm{H}_{0}$ (control) yaitu $35,57 \mathrm{~cm}$ dan hasil terendah pada konsentrasi
$\mathrm{H}_{1}(5 \mathrm{ml} / \mathrm{l}$ air) yaitu $34,67 \mathrm{~cm}$. Pengaruh perlakuan interaksi media tanam dan konsentrasi pupuk hayati Agrobost terhadap tinggi tanaman sawi hijau dapat dilihat pada Gambar 3

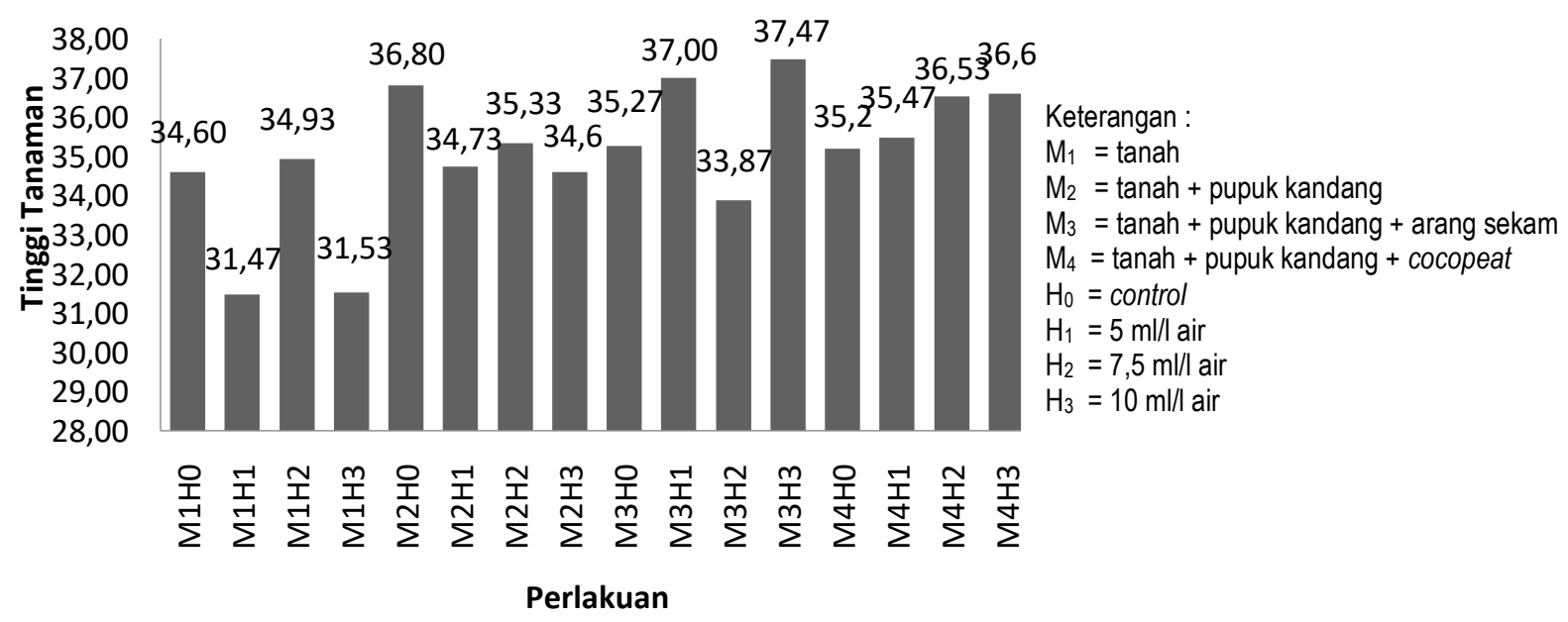

Gambar 3. Perlakuan interaksi media tanam dan konsentrasi pupuk hayati Agrobost terhadap rata-rata tinggi tanaman sawi hijau (Brassica juncea L).

Berdasarkan gambar diatas bahwa interaksi media tanam dan konsentrasi pupuk hayati Agrobost menghasilkan pertumbuhan tinggi tanaman sawi hijau tertinggi pada Interaksi perlakuan $\mathrm{M}_{3} \mathrm{H}_{3}$ (tanah + pupuk kandang + arang sekam) dan konsentrasi pupuk hayati Agrobost (10 $\mathrm{ml} / \mathrm{l}$ air) yaitu $37,5 \mathrm{~cm}$ dan terendah pada interksi $\mathrm{M}_{1} \mathrm{H}_{1}$ (tanah) dan konsentrasi pupuk hayati Agrobost (5 ml/l air) yaitu $31.47 \mathrm{~cm}$.

2. Jumlah Daun (helai)

Pengaruh perlakuan media tanam terhadap jumlah daun tanaman sawi hijau dapat dilihat pada Gambar 4 


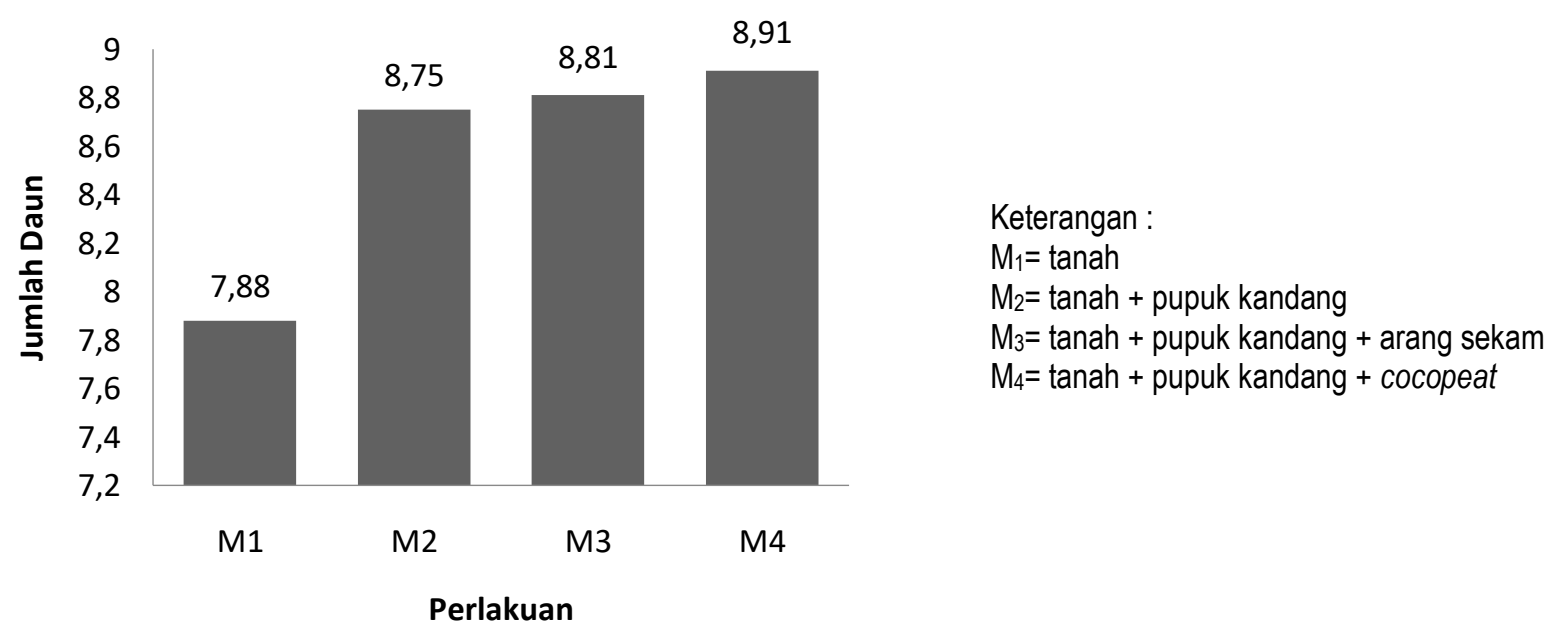

Gambar 4. Perlakuan media tanam terhadap rata-rata jumlah daun tanaman sawi hijau (Brassica juncea L).

Berdasarkan gambar di atas bahwa perlakuan media tanam menghasilkan pertumbuhan jumlah daun tertinggi terdapat pada media tanam $\mathrm{M}_{4}$ (tanah + pupuk kandang + cocopeat) yaitu 8,91 helai dan terendah pada $\mathrm{M}_{1}$ (tanah) yaitu 7,88 helai.

Pengaruh perlakuan konsentrasi pupuk hayati Agrobost terhadap jumlah daun tanaman sawi hijau dapat dilihat pada Gambar 5.

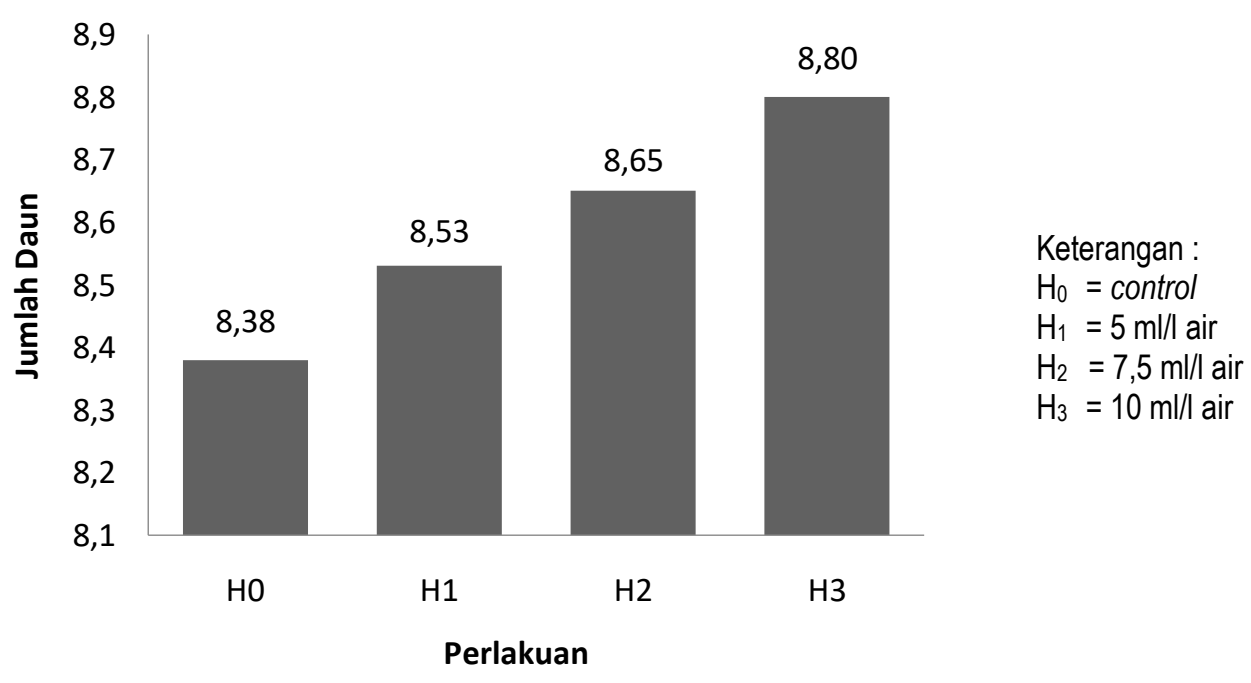

Gambar 5. Pengaruh konsentrasi pupuk hayati Agrobost terhadap rata-rata jumlah daun tanaman sawi hijau (Brassica juncea L).

Berdasarkan gambar di atas bahwa perlakuan konsentrasi pupuk hayati Agrobost menghasilkan pertumbuhan jumlah daun tanaman sawi hijau terbanyak pada perlakuan $\mathrm{H}_{3}(10 \mathrm{ml} / \mathrm{l}$ air) yaitu 8,80 helai dan hasil terendah pada konsentrasi
$\mathrm{H}_{0}$ (control) yaitu 8,38 helai. Pengaruh perlakuan interaksi media tanam (M) dan konsentrasi pupuk hayati Agrobost $(\mathrm{H})$ terhadap jumlah daun tanaman sawi hijau dapat dilihat pada Gambar 6. 


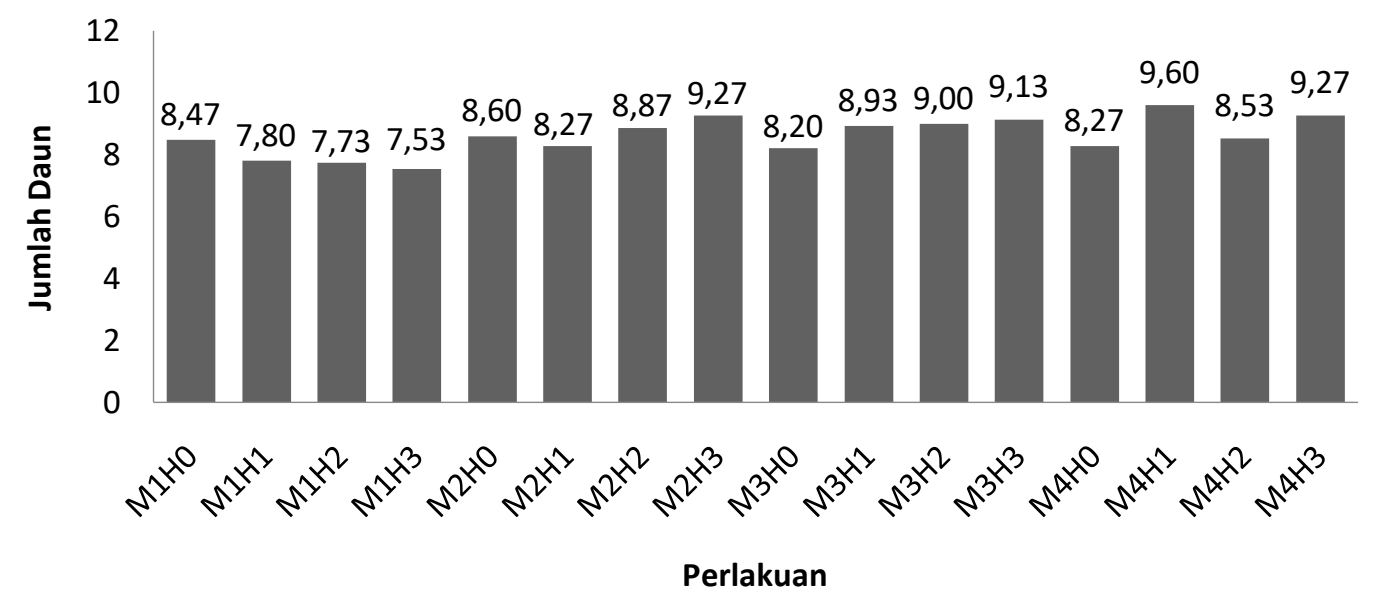

Gambar 6. Perlakuan interaksi media tanam dan konsentrasi pupuk hayati Agrobost terhadap rata-rata

Keterangan: $M_{1}=$ tanah

$\mathrm{M}_{2} \quad=$ tanah + pupuk kandang

$\mathrm{M}_{3}=$ tanah + pupuk kandang + arang sekam

$\mathrm{M}_{4}=$ tanah + pupuk kandang + cocopeat

$\mathrm{H}_{0}=$ control

$\mathrm{H}_{1} \quad=5 \mathrm{ml} / \mathrm{l}$ air

$\mathrm{H}_{2} \quad=7,5 \mathrm{ml} / \mathrm{l}$ air

$\mathrm{H}_{3} \quad=10 \mathrm{ml} / \mathrm{l}$ air

Berdasarkan gambar di atas bahwa perlakuan interaksi media tanam (M) dan konsentrasi pupuk Agrobost $(\mathrm{H})$ menghasilkan jumlah daun tanaman sawi hijau terbanyak pada Interaksi perlakuan $\mathrm{M}_{4} \mathrm{H}_{1}$ (tanah + pupuk kandang + cocopeat) dan konsentrasi pupuk hayati agrobost $(5$ $\mathrm{ml} / \mathrm{l}$ air) yaitu 9,60 helai dan interaksi M1H3 (media tanam (tanah) dan konsentrasi pupuk hayati agrobost (10 $\mathrm{ml} / \mathrm{l}$ air) merupakan interaksi terendah yaitu 7.53 helai.

\section{Berat Berangkasan Basah Tanaman (g)}

Hasil analisis keragaman pengaruh perlakuan media tanam menunjukkan pengaruh sangat nyata terhadap pertumbuhan dan produksi tanaman sawi hijau. Hasil uji lanjut pengaruh media tanam ditunjukkan pada Tabel 4.

Tabel 4. Hasil uji lanjut Beda Nyata Jujur (BNJ) taraf $5 \%$ penambahan media tanam terhadap pertumbuhan dan produksi tanaman sawi hijau.

\begin{tabular}{lc}
\hline \multicolumn{1}{c}{ Penambahan Media Tanam } & Nilai rata-rata \\
\hline$M_{4}$ (tanah + pupuk kandang + cocopeat) & $78,48 \mathrm{a}$ \\
$M_{3}($ tanah + pupuk kandang +arang sekam) & $69,41 \mathrm{a}$ \\
$M_{2}$ (tanah + pupuk kandang) & $67,91 \mathrm{a}$ \\
$M_{1}$ (tanah) & $48,57 \mathrm{~b}$ \\
\hline
\end{tabular}

Keterangan: Angka-angka yang diikuti huruf yang sama adalah tidak berbeda nyata pada taraf $5 \%$.

Hasil uji BNJ taraf $5 \%$ pengaruh media tanam terhadap pertumbuhan dan produksi tanaman sawi hijau menunjukkan bahwa perlakuan $\mathrm{M}_{4}$ (tanah + pupuk kandang + cocopeat) berpengaruh tidak nyata terhadap perlakuan $\mathrm{M}_{3}$ (tanah + pupuk kandang + arang sekam) dan perlakuan $\mathrm{M}_{2}$ (tanah + pupuk kandang). Perlakuan $\mathrm{M}_{3}$ (tanah + pupuk kandang + arang sekam) berpengaruh tidak nyata terhadap perlakuan $\mathrm{M}_{2}$ (tanah + pupuk kandang). Perlakuan $\mathrm{M}_{4}$ (tanah + pupuk kandang + cocopeat), $M_{3}$ (tanah + pupuk kandang + arang sekam) dan $\mathrm{M}_{2}$ (tanah + pupuk 
kandang) berpengaruh nyata terhadap perlakuan $\mathrm{M}_{1}$ (tanah).

Pengaruh perlakuan konsentrasi pupuk hayati Agrobost terhadap berat berangkasan basah per tanaman tanaman sawi dapat dilihat pada Gambar 7.

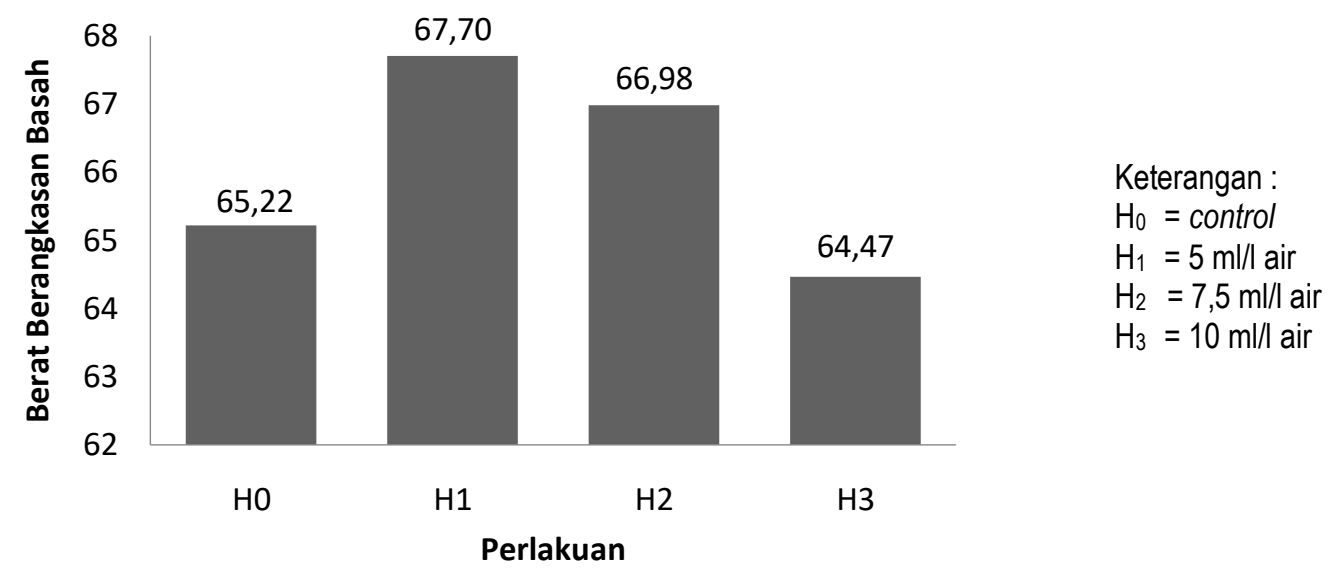

Gambar 7. Pengaruh konsentrasi pupuk hayati Agrobost terhadap rata-rata berat berangkasan basah tanaman sawi hijau (Brassica juncea L).

Berdasarkan gambar di atas bahwa perlakuan konsentrasi pupuk Agrobost menghasilkan berat berangkasan basah tanaman sawi hijau tertinggi pada konsentrasi $\mathrm{H}_{1}(5 \mathrm{ml} / \mathrm{l}$ air $)$ yaitu $67.70 \mathrm{~g}$ dan paling rendah pada konsentrasi pupuk hayati Agrobost $\mathrm{H}_{3}(10 \mathrm{ml} / \mathrm{l}$ air) yaitu $64,47 \mathrm{~g}$. Pengaruh perlakuan interaksi media tanam dan konsentrasi pupuk hayati Agrobost terhadap berat berangkasan basah tanaman sawi hijau, dapat dilihat pada Gambar 8.

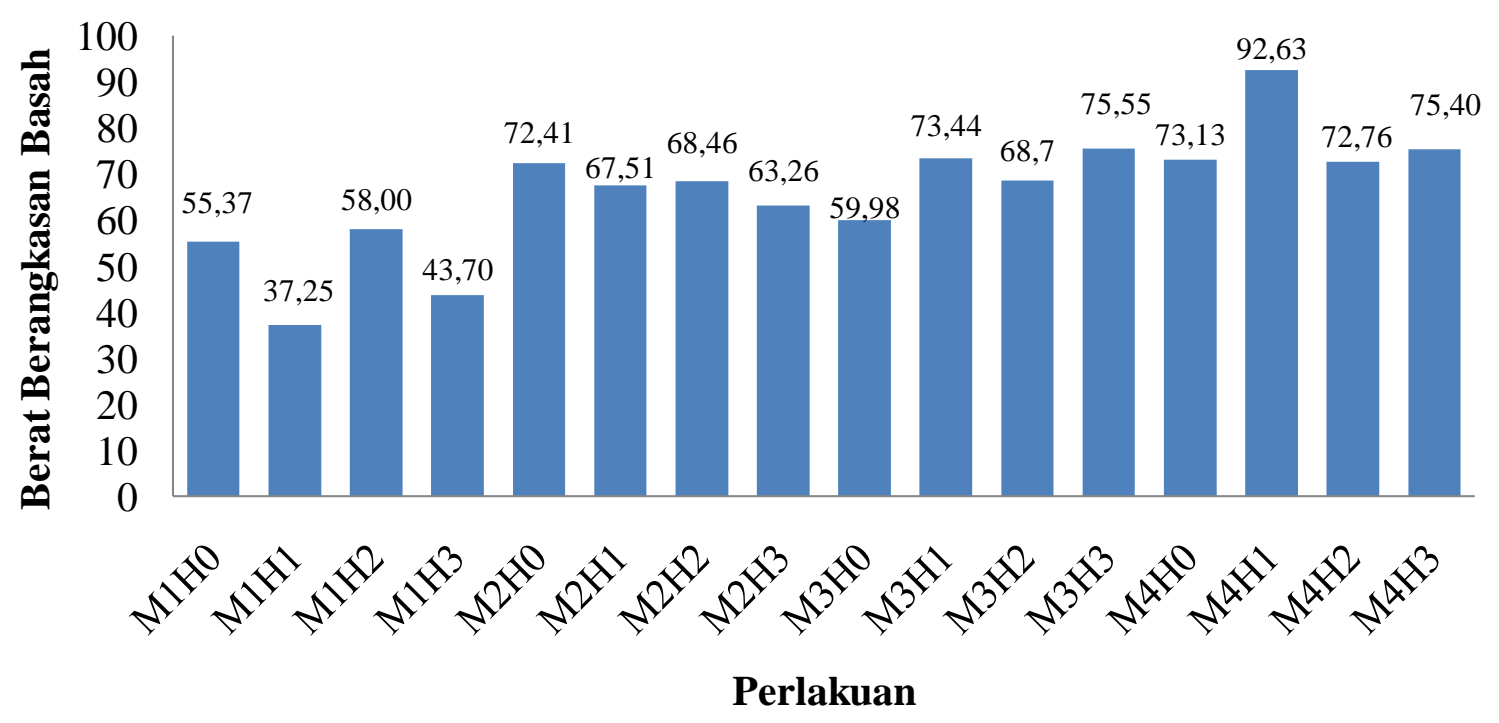

Gambar 8. Perlakuan interaksi media tanam dan konsentrasi pupuk hayati Agrobost terhadap rata-rata berat berangkasan basah tanaman sawi hijau (Brassica juncea L).

Berdasarkan gambar di atas bahwa perlakuan interaksi media tanam dan konsentrasi pupuk hayati Agrobost menghasilkan berat berangkasan basah tanaman sawi hijau tertinggi
Pada interaksi $\mathrm{M}_{4} \mathrm{H}_{1}$ (tanah + pupuk kandang + cocopeat) dan konsentrasi pupuk hayati Agrobost (5 $\mathrm{m} / \mathrm{l}$ air) yaitu $92,63 \mathrm{~g}$, dan terendah pada interaksi 
$\mathrm{M}_{1} \mathrm{H}_{1}$ (tanah) dan konsentrasi pupuk hayati Agrobost (5 ml/l air) yaitu $37,23 \mathrm{~g}$.

\section{Produksi Per Tanaman (g)}

Hasil analisis keragaman pengaruh perlakuan media tanam menunjukkan berpengaruh sangat nyata terhadap pertumbuhan dan produksi tanaman sawi hijau. Hasil uji lanjut penambahan media tanam ditunjukkan pada Tabel 5 .

Tabel 5. Hasil uji lanjut Beda Nyata Jujur (BNJ) taraf 5\% penambahan media tanam terhadap pertumbuhan dan produksi tanaman sawi hijau.

\begin{tabular}{lc}
\hline \multicolumn{1}{c}{ Penambahan Media Tanam } & Nilai rata-rata \\
\hline$M_{4}($ tanah + pupuk kandang + cocopeat) & $74,02 \mathrm{a}$ \\
$M_{3}$ (tanah + pupuk kandang +arang sekam) & $64,99 \mathrm{a}$ \\
$M_{2}$ (tanah + pupuk kandang) & $64,05 \mathrm{a}$ \\
$\mathrm{M}_{1}$ (tanah) & $45,45 \mathrm{~b}$ \\
\hline
\end{tabular}

Keterangan: Angka-angka yang diikuti huruf yang sama adalah tidak berbeda nyata pada taraf $5 \%$.

Hasil uji BNJ taraf $5 \%$ pengaruh media tanam terhadap pertumbuhan dan produksi tanaman sawi hijau menunjukkan bahwa perlakuan $\mathrm{M}_{4}$ (tanah + pupuk kandang + cocopeat) berpengaruh tidak nyata terhadap perlakuan $\mathrm{M}_{3}$ (tanah + pupuk kandang + arang sekam) dan perlakuan $M_{2}$ (tanah + pupuk kandang), dan perlakuan $\mathrm{M}_{3}$ (tanah + pupuk kandang + arang sekam) berpengaruh tidak nyata terhadap perlakuan $\mathrm{M}_{2}$ (tanah + pupuk kandang). Perlakuan $\mathrm{M}_{4}$ (tanah + pupuk kandang + cocopeat), $\mathrm{M}_{3}$ (tanah + pupuk kandang + arang sekam) dan $\mathrm{M}_{2}$ (tanah + pupuk kandang) berpengaruh nyata terhadap perlakuan $M_{1}$ (tanah). Pengaruh perlakuan konsentrasi pupuk hayati Agrobost terhadap produksi per hektar tanaman sawi hijau, dapat dilihat pada Gambar 9.

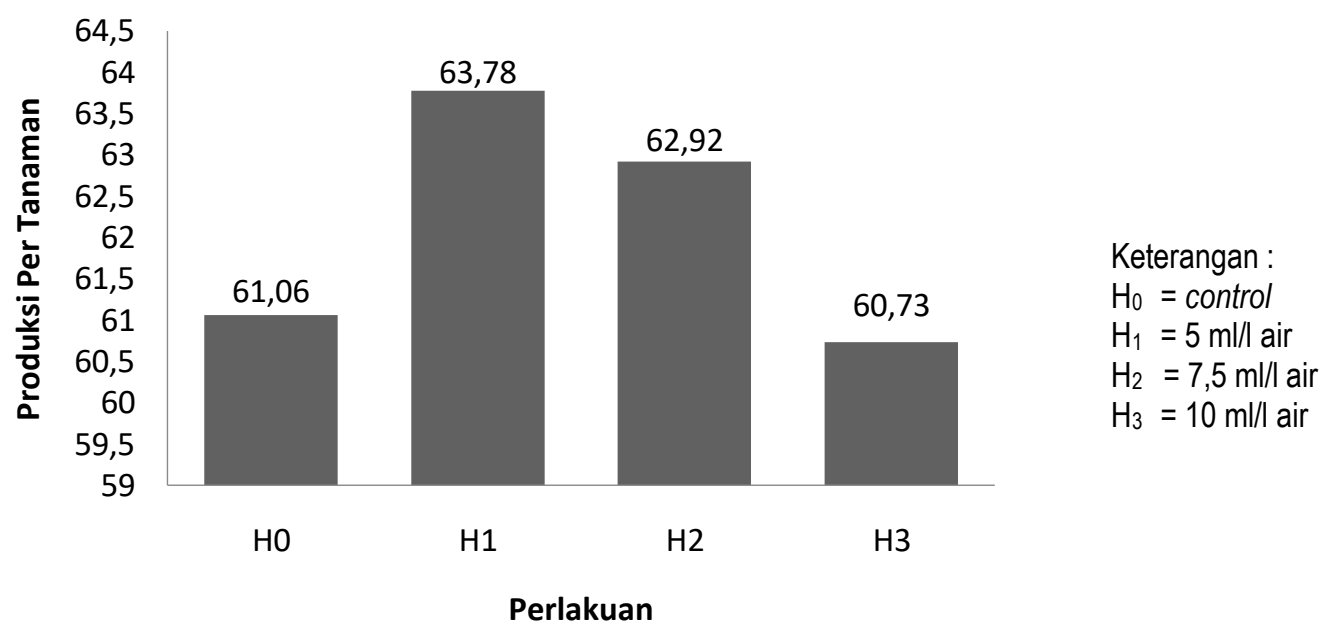

Gambar 9. Pengaruh media tanam terhadap rata-rata produksi per tanaman sawi hijau (Brassica juncea $\mathrm{L})$.

Berdasarkan gambar di atas bahwa perlakuan konsentrasi pupuk hayati Agrobost menghasilkan produksi per tanaman sawi hijau tertinggi pada perlakuan $\mathrm{H}_{1}(5 \mathrm{ml} / \mathrm{l}$ air) terberat yaitu $63.78 \mathrm{~g}$ dan paling rendah pada perlakuan $\mathrm{H}_{3}(10$ $\mathrm{ml} / \mathrm{l}$ air) yaitu $60,7 \mathrm{~g}$. Pengaruh perlakuan interaksi media tanam dan konsentrasi pupuk hayati Agrobost terhadap produksi per tanaman sawi hijau, dapat dilihat pada Gambar 10. 


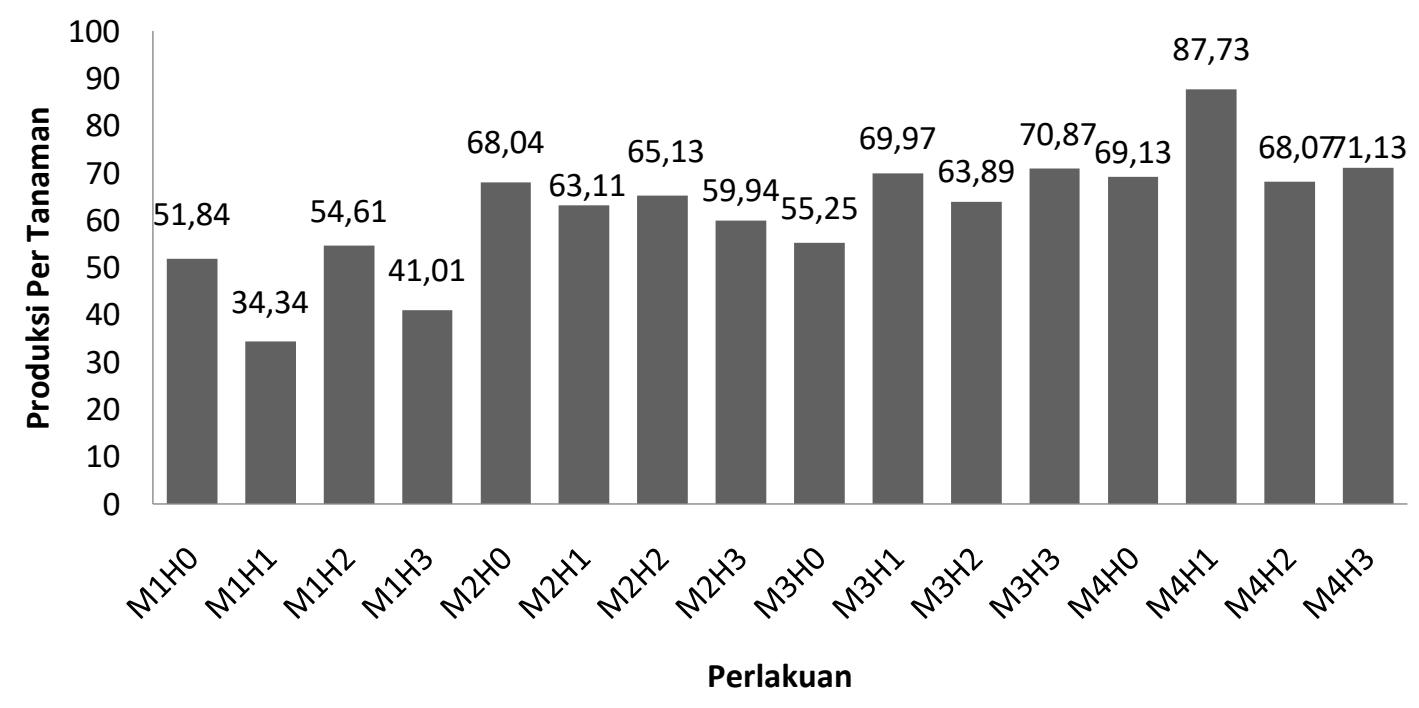

Gambar 10. Perlakuan interaksi media tanam dan konsentrasi pupuk hayati Agrobost terhadap rata-rata produksi per tanaman sawi hijau (Brassica juncea L).

Berdasarkan gambar di atas bahwa perlakuan interaksi media tanam dan konsentrasi pupuk hayati agrobost menghasilkan produksi pertanaman sawi hijau tertinggi pada interaksi $\mathrm{M}_{4} \mathrm{H}_{1}$ (tanah + pupuk kandang + cocopeat) dan konsentrasi pupuk Agrobost (5 ml/l air) yaitu 87,73 g, dan perlakuan terendah pada perlakuan $\mathrm{M}_{1} \mathrm{H}_{1}$ (tanah) dan konsentrasi pupuk hayati Agrobost
(5 ml/l air) yaitu $34,33 \mathrm{~g}$.

\section{Produksi Per Hektar (ton)}

Hasil analisis keragaman menunjukkan bahwa media tanam pada produksi per hektar berpengaruh sangat nyata terhadap pertumbuhan dan produksi tanaman sawi hijau. Hasil uji lanjut perlakuan media tanam ditunjukkan pada Tabel 6 .

Tabel 6. Hasil uji lanjut Beda Nyata Jujur (BNJ) taraf 5\% perlakuan media tanam terhadap pertumbuhan dan produksi tanaman sawi.

\begin{tabular}{lc}
\hline \multicolumn{1}{c}{ Penambahan Media Tanam } & Nilai rata-rata \\
\hline $\mathrm{M}_{4}$ (tanah + pupuk kandang + cocopeat) & $18,46 \mathrm{a}$ \\
$\mathrm{M}_{3}$ (tanah + pupuk kandang +arang sekam) & $16,22 \mathrm{a}$ \\
$\mathrm{M}_{2}$ (tanah + pupuk kandang) & $15,98 \mathrm{a}$ \\
$\mathrm{M}_{1}$ (tanah) & $11,33 \mathrm{~b}$ \\
\hline
\end{tabular}

Keterangan: Angka-angka yang diikuti huruf yang sama adalah tidak berbeda nyata pada taraf $5 \%$.

Hasil uji lanjut BNJ taraf $5 \%$ perlakuan media tanam terhadap pertumbuhan dan produksi tanaman sawi hijau (Brassica juncea L) menunjukkan bahwa perlakuan $\mathrm{M}_{4}$ (tanah + pupuk kandang + cocopeat) berbeda tidak nyata terhadap perlakuan $\mathrm{M}_{3}$ (tanah + pupuk kandang + arang sekam) dan perlakuan $\mathrm{M}_{2}$ (tanah + pupuk kandang), dan $\mathrm{M}_{3}$ (tanah + pupuk kandang + arang sekam) tetapi berbeda tidak nyata terhadap perlakuan $\mathrm{M}_{2}$ (tanah + pupuk kandang). Perlakuan $\mathrm{M}_{4}$ (tanah + pupuk kandang + cocopeat), $\mathrm{M}_{3}$ (tanah + pupuk kandang + arang sekam) dan $\mathrm{M}_{2}$ (tanah + pupuk kandang) berbeda nyata dengan perlakuan $M_{1}$ (tanah). Pengaruh perlakuan konsentrasi terhadap produksi per hektar tanaman sawi hijau, dapat dilihat pada Gambar 11. 


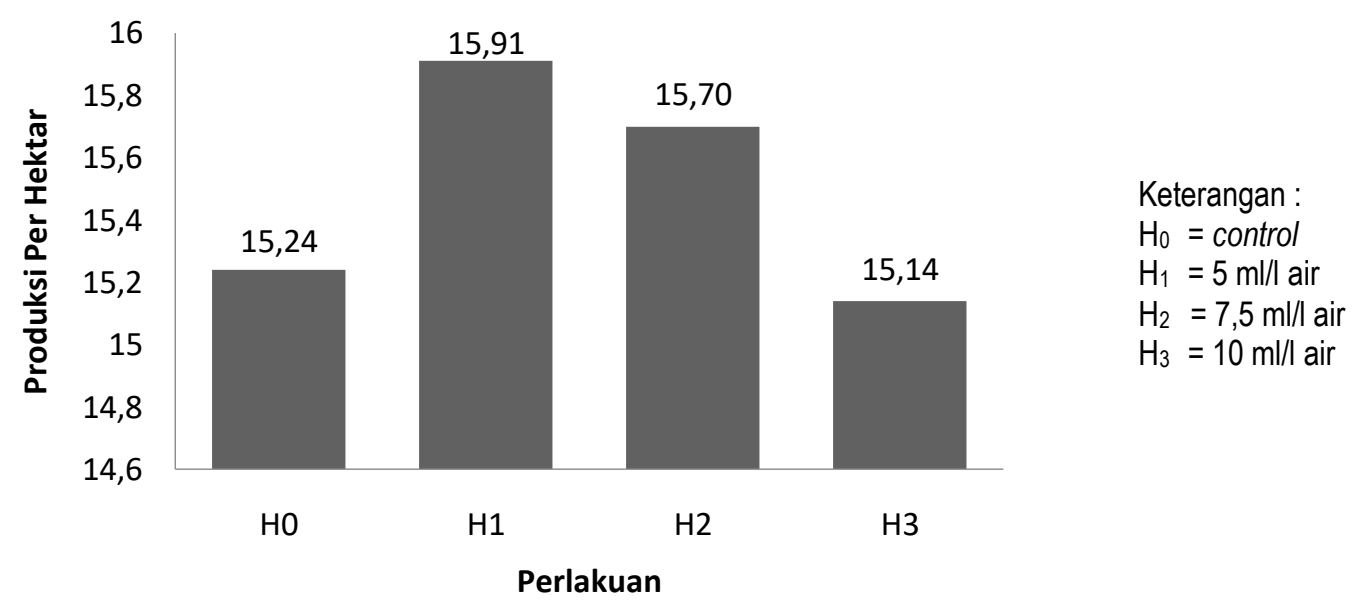

Gambar 11. Pengaruh konsentrasi pupuk hayati Agrobost terhadap rata-rata produksi per hektar tanaman sawi hijau (Brassica juncea L).

Berdasarkan gambar di atas bahwa perlakuan konsentrasi pupuk hayati Agrobost menghasilkan produksi per hektar tanaman sawi hijau tertinggi pada konsentrasi $\mathrm{H}_{1}$ (5 ml/l air) yaitu 15,91 ton dan paling rendah pada konsentrasi $\mathrm{H}_{3}(10 \mathrm{ml} / \mathrm{l}$ air) yaitu 15,14 ton.
Pengaruh perlakuan interaksi media tanam dan konsentrasi pupuk hayati Agrobost terhadap produksi per hektar tanaman sawi hijau, dapat dilihat pada Gambar 12.

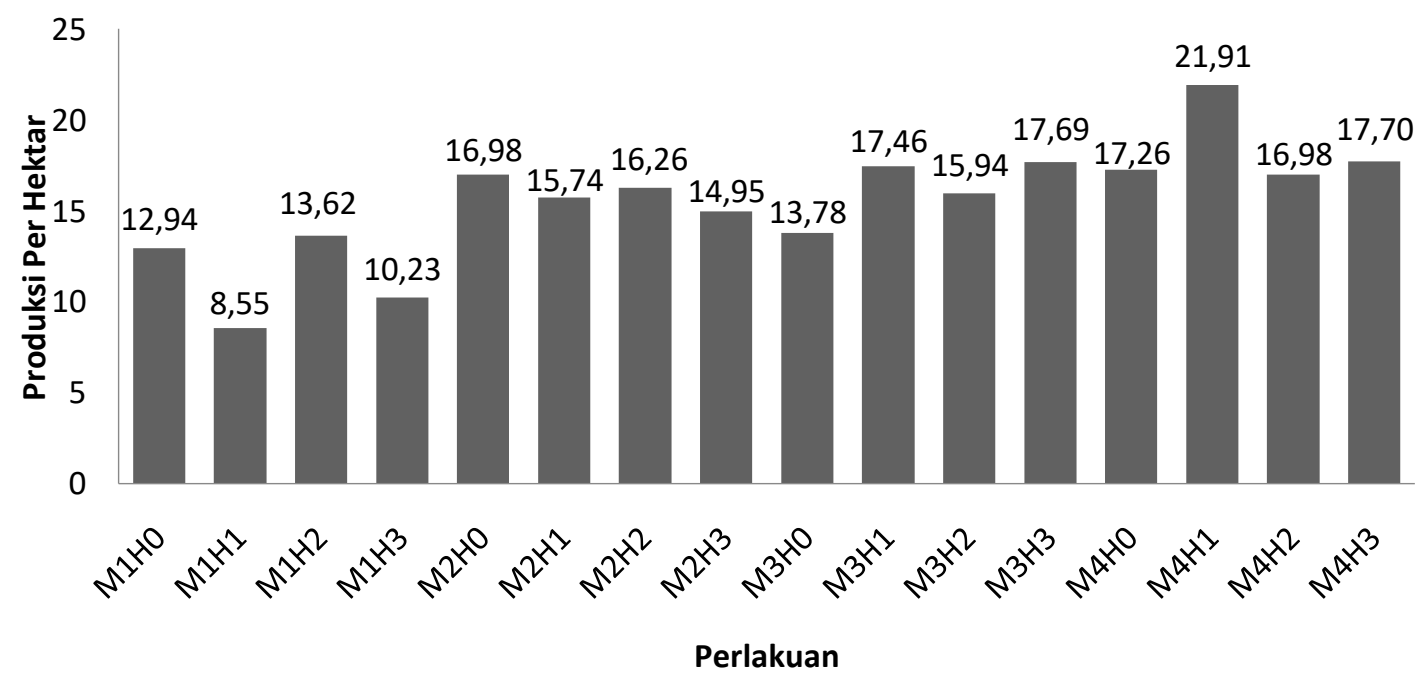

Gambar 12. Perlakuan interaksi media tanam dan konsentrasi pupuk hayatim Agrobost terhadap rata-rata produksi per hektar tanaman sawi hijau (Brassica juncea L).

Berdasarkan gambar di atas bahwa perlakuan interaksi media tanam dan konsentrasi pupuk hayati Agrobost menghasilkan produksi per hektar tanaman sawi hijau tertinggi pada interaksi $\mathrm{M}_{4} \mathrm{H}_{1}$ (tanah + pupuk kandang + cocopeat) dan konsentrasi pupuk hayati Agrobost (5 ml/l air) yaitu 21,91 ton dan terendah pada interaksi $\mathrm{M}_{1} \mathrm{H}_{1}$ (tanah) dan konsentrasi pupuk hayati Agrobost (5 ml/l air) yaitu 8,55 ton.

\section{Pembahasan}

Media tanam merupakan komponen utama ketika akan bercocok tanam, untuk dapat menentukan 
media tanam yang tepat, harus sesuai dengan jenis tanaman yang akan di tanam, secara umum media tanam harus dapat menjaga kelembaban daerah sekitar akar, menyediakan cukup udara, dan dapat menahan ketersediaan unsur hara.

Berdasarkan hasil analisis keragaman, perlakuan media tanam yang tertinggi yaitu pada perlakuan $\mathrm{M}_{4}$ (tanah + pupuk kandang + cocopeat) pada peubah tinggi tanaman, jumlah daun, berat berangkasan basah, produksi per tanaman, dan produksi per hektar, ini diduga karena sifat cocopeat yang dapat menyimpan air di dalam pori-pori, sehingga larutan pupuk cair dapat tersimpan di dalam pori-pori cocopeat yang diperlukan oleh tanaman. Menurut Embarsari et al (2015), media cocopeat pada dasarnya memiliki kapasitas menahan air cukup tinggi, memiliki pori mikro yang mampu menghambat gerakan air lebih besar sehingga menyebabkan ketersediaan air lebih tinggi. Selain itu, Cocopeat mengandung unsur hara yang dibutuhkan tanaman. Unsur hara yang terkandung di dalam cocopeat yaitu unsur hara makro dan mikro yang terdapat pada serbuk kelapa (cocopeat) antara lain $\mathrm{K}, \mathrm{P}, \mathrm{Ca}, \mathrm{Mg}$, $\mathrm{Na}$. Unsur hara makro yaitu nutrisi yang dibutuhkan dalam jumlah banyak dan unsur mikro yaitu nutrisi yang dibutuhkan dalam jumlah sedikit. Pertumbuhan akar yang baik mampu menyerap nutrisi yang tersedia terutama unsur $\mathrm{N}$ yang sangat berperan dalam pembentukan tinggi tanaman. Syarif, 1985 dalam Riyawati (2012) menambahkan bahwa, nitrogen yang cukup pada tanaman akan memperlancar proses pembelahan sel dengan baik karena unsur nitrogen mempunyai peranan utama untuk merangsang pertumbuhan secara keseluruhan khususnya pertumbuhan batang sehingga memacu pertumbuhan tinggi tanaman.

Kebutuhan tanaman akan setiap unsur hara tergantung pada ketersediaan dari semua unsur hara yang ada dalam tanah. Hal ini berkaitan dengan kenyataan bahwa hasil maksimum yang dapat dicapai bila semua kondisi pertumbuhan termasuk penyediaan hara berada dalam kondisi optimal, dikatakan optimal bila unsur tersedia dalam jumlah yang tepat karena kekurangan atau kelebihan salah satu unsur hara akan dapat mengurangi efesiensi dari hara yang lain (Novizan, 2007).

Berdasarkan hasil analisis keragaman perlakuan konsentrasi pupuk hayati Agrobost pada perlakuan $\mathrm{H}_{1}$ $(5 \mathrm{ml} / /$ air) adalah perlakuan yang terbaik, pada peubah berat berangkasan basah, produksi pertanaman, dan produksi per hektar, ini diduga konsentrasi $5 \mathrm{ml} / \mathrm{l}$ air mikrobia yang terkandung dapat bekerja dengan optimal, menurut Wahyuningratri et al. (2017) pemberian konsentrasi $5 \mathrm{ml} / \mathrm{l}$ air pupuk hayati dapat meningkatkan kesuburan tanah karena bakteri yang terkandung dalam konsentrasi tersebut dapat bekerja maksimal dalam merombak dan memfasilitasi asupan unsur hara yang dibutuhkan tanaman. Agus (1997) menambahkan bahwa aktivitas mikroorganisme dapat membantu pertumbuhan tanaman dan mempengaruhi kesuburan tanah melalui perannya memperlancar siklus unsur hara dan menyuplai hormon-hormon serta enzim yang berguna bagi pertumbuhan tanaman.

Berdasarkan uji analisis keragaman menunjukkan interaksi media tanam dan konsentrasi pupuk hayati Agrobost tidak berpengaruh nyata terhadap semua peubah yang diamati, hal ini diduga karena mikrobia yang terkandung di dalam pupuk hayati Agrobost tidak tersedia atau mikrobia mengalami masa dorman (tidur) sehingga belum dapat membantu penyuburan tanah. Hal ini sesuai pernyataan Asroh (2010), bahwa bila larutan pupuk hayati disemprotkan pada tanaman atau permukaan tanah, maka mikrobia yang ada belum tentu dapat hidup dan berkembang karena kondisi lingkungan yang mungkin tidak sesuai, antara lain tidak tersedia makanan yang mudah dicerna, temperatur udara yang terlalu tinggi, kelembaban yang kurang, oksigen yang berlebih dan tanpa naungan, menyebabkan mikrobia tersebut tidak berkembang dan mati.

Pengaruh yang tidak nyata terhadap seluruh parameter yang diamati, diduga interaksi kedua perlakuan kurang saling mendukung satu sama lainnya, tanaman akan tumbuh baik apabila ketersedian unsur hara terpenuhi dan kondisi media tanam yang optimal, namun apabila salah satu faktor tidak terpenuhi maka proses pertumbuhan tanaman akan terhambat. Hal ini sesuai dengan pendapat Nurhayati (2010), bahwa pertumbuhan tanaman yang baik dapat tercapai bila faktor yang mempengaruhi pertumbuhan berimbang dan menguntungkan. Hanafiah (1991) menambahkan bahwa, apabila tidak ada interaksi, berarti pengaruh suatu faktor sama untuk semua taraf faktor lainnya dan sama dengan pengaruh utamanya. Sesuai dengan pernyataan tersebut, maka dapat disimpulkan bahwa kedudukan dari kedua faktor adalah sama-sama mendukung pertumbuhan tanaman, tetapi tidak saling mendukung bila salah satu faktor menutupi faktor lainnya. Lebih lanjut Sutedjo (2001), menjelaskan bahwa bila salah satu faktor lebih kuat pengaruhnya dari faktor lain sehingga faktor lain tersebut tertutupi dan masing-masing faktor mempunyai sifat yang jauh berbeda pengaruh dan sifat kerjanya, maka tidak akan menghasilkan hubungan nyata dalam mempengaruhi pertumbuhan tanaman.

\section{DAFTAR PUSTAKA}


Agoes, D. S. 1994. Aneka Jenis Media Tanam dan Penggunaannya. Jakarta: Penebar swadaya.

Agro Dahlia Profitmas PT. 2008. Cara Pemakaian Pupuk Biolog Agrobost. [Online] http://pupuksmsagrobost.blogspot.com/2008/06/ pupuk-sms-agrobost-solusi-menujusukses.html, Diakses pada tanggal 28 Mei 2019.

Cahyono, B. 2003. Teknik dan Strategi Budidaya Sawi Hijau. Yogyakarta: Yayasan Pustaka Nusatama.

Daniel, A. 2008. Budidaya Melon Hibrida. Pustaka Baru Press. Yogyakarta.

Direktorat Tanaman Sayuran dan Tanaman Hias. 2012. Jakarta: Direktorat Jendral Hortikultura dan Aneka Tanaman.

Distributor oleh BJS Indonesia. 2010. [Online] dari file:///C:/Users/user/Downloads |BAB $\% 201 \% 252 \mathrm{CI} \% 252 \mathrm{CIII.rtf}$, diakses pada tanggal 30 Juli 2019.

Endrizal, yanti,L., Susilawati, E., Salvia E., Murni WS., dan Firdaus. 2010. Budidaya Tanaman Sayuran. Balai Pengkajian Teknologi Pertanian (BPTP) Jambi.

Fahmi, Z.I. 2013. Media tanam sebagai faktor eksternal yang mempengaruhi pertumbuhan tanaman. Balai besar perbenihan dan proteksi tanaman perkebunan Surabaya.

Goenadi, D.H. 2006. Pupuk dan Teknologi Pemupukan Berbasis Hayati : dari Cawan Petri ke Lahan Petani. Jakarta. Yayasan John Hi-Tech Idetama.

Hanafiah, K.A. Rancangan Percobaan Teori dan Aplikasi. Raja Grafindo Persada. Jakarta.

Haryanto, E., Suhartini, T., dan Rahayu, E. 2003. Sawi Dan Selada. Jakarta: Penebar Swadaya.

Hayati E, Sabaruddin dan Rahmawati. 2012. Pengaruh Jumlah Mata Tunas Dan Komposisi Media Tanam Terhadap Pertumbuhan Setek Tanaman Jarak Pagar (Jatropha curcas L.) Jurnal Agrista Vol. 16 No. 3, 2012

Isroi. 2008. Kompos. Peneliti pada Balai Penelitian Bioteknologi Perkebunan Indonesia. [Online] dari

http://isroi.files.wordpress.com/2008/02/kompos. pdf. Diakses Pada 30 Agustus 2019.

Nazaruddin. 2003. Budidaya dan Pengantar Panen Sayuran Dataran Rendah. Penebar Swadaya: Jakarta.

Pracaya. 2011. Bertanam Sayur Organik. Penebar Swadaya : Jakarta.

Rahmat, R. 2007. Bertanam Petsai Dan Sawi. Yogyakarta: Kanisius.

Risyad, S dan Ainun, N. 2014. Pengaruh Media Tanam dan Pupuk Hayati Agrobost Terhadap Pertumbuhan dan Hasil Produksi Melon (Cucumis melo, L.) dalam Polybag. [Online] dari file:///C:/Users/user/Downloads/307Article\%20Text-1248-1-1020171110\%20.pdf diakses pada tanggal 28 Mei 2019.

Rukmana, 2002. Bertanam Petsai dan Sawi. Kanisius: Yogyakarta.

Setyoadji, D. 2015. Tanaman Hidroponik. Yogyakarta: Araska.

Septiani, Dewi. 2012. Pengaruh Pemberian Arang Sekam Padi Terhadap Pertumbuhan Dan Hasil Tanaman Cabai Rawit (Capsicum frutescens). Skripsi. Lampung : Politeknik.

Simanungkalit, R.D.M. 2006. Pupuk Organik dan Pupuk Hayati. Bogor: Balai Besar Penelitian dan Pengembangan Sumberdaya Lahan Pertanian.

Sunarjono H. 2004. Bertanam 30 Jenis Sayur. Jakarta: Penebar Swadaya.

Supriati, Y dan E. Herliana. 2010. Bertanam 15 Sayuran Organik dalam Pot. Penebar Swadaya: Jakarta.

Susanti, T. 2011. Pengaruh air kelapa muda terhadap pertumbuhan tanaman sawi (Brassica juncea L.) dengan interval pemberian yang berbeda. Skripsi. Fakultas Pertanian dan Peternakan Universitas Islam Negeri Sultan Syarif Kasim Riau. Pekanbaru.

Susila, A. D. 2006. Fertigasi pada Budidaya Tanaman Sayuran di dalam Greenhouse. Bagian 
Produksi Tanaman, Departemen Agronomi dan Hortikultura. Fakultas Pertanian. IPB. Bogor.

Wira. N.J. 2000. Pengaruh Campuran Bahan Organik Terhadap Pertumbuhan dan Hasil Tanaman Seledri. (Skripsi). Fakultas Pertanian. Universitas Mataram.149h.

Wuryaningsih, S. 2008. Media Tanam Tanaman Hias. [Online] dari file:///C:/Users/user/Downloads/410-868-1PB\%20(1).pdf, diakses pada tanggal 28 Mei 2019 